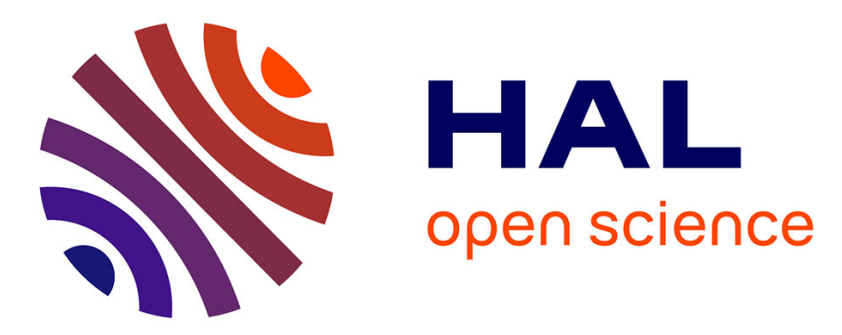

\title{
Electrosynthesis and electrochemical properties of porphyrin dimers with pyridinium as bridging spacer
}

Delphine Schaming, Sonia Marggi-Poullain, Iftikhar Ahmed, Rana Farha, Michel Goldmann, Jean-Paul Gisselbrecht, Laurent Ruhlmann

\section{- To cite this version:}

Delphine Schaming, Sonia Marggi-Poullain, Iftikhar Ahmed, Rana Farha, Michel Goldmann, et al.. Electrosynthesis and electrochemical properties of porphyrin dimers with pyridinium as bridging spacer. New Journal of Chemistry, 2011, 35 (11), pp.2534-2543. 10.1039/c1nj20177h . hal-01239021

\section{HAL Id: hal-01239021 \\ https://hal.science/hal-01239021}

Submitted on 3 Sep 2021

HAL is a multi-disciplinary open access archive for the deposit and dissemination of scientific research documents, whether they are published or not. The documents may come from teaching and research institutions in France or abroad, or from public or private research centers.
L'archive ouverte pluridisciplinaire HAL, est destinée au dépôt et à la diffusion de documents scientifiques de niveau recherche, publiés ou non, émanant des établissements d'enseignement et de recherche français ou étrangers, des laboratoires publics ou privés. 


\title{
Electrosynthesis and electrochemical properties of porphyrin dimers with pyridinium as bridging spacer
}

\author{
Delphine Schaming, ${ }^{a}$ Sonia Marggi-Poullain, ${ }^{a}$ Iftikhar Ahmed, ${ }^{a}$ Rana Farha, ${ }^{b c}$ \\ Michel Goldmann, ${ }^{b d}$ Jean-Paul Gisselbrecht ${ }^{e}$ and Laurent Ruhlmann*ae
}

Two porphyrin dimers (more precisely two isomers) with pyridinium as bridging spacer have been obtained by controlled potential electrolysis. This method is based on a nucleophilic substitution of a porphyrin substituted by a pyridyl group (namely 5,10,15-tritolyl-20-(4-pyridyl)porphyrin $\left(\mathrm{H}_{2} \mathrm{~T}_{3} \mathrm{P}\right.$-4-Py) or 5,10,15-tritolyl-20-(3-pyridyl)porphyrin $\left(\mathrm{H}_{2} \mathrm{~T}_{3} \mathrm{P}-3\right.$-Py) $)$ on an electrogenerated radical cation of a zinc $\beta$-octaethylporphyrin (ZnOEP). The new compounds have been characterized by HR-MS, ${ }^{1} \mathrm{H}$ NMR, UV-vis and fluorescence spectroscopies. Difference of electrochemical behaviour of the pyridinium spacers between the two dimers has been also discussed.

\section{Introduction}

Porphyrins constitute a major class of chemical compounds due to their optical and redox properties, ${ }^{1,2}$ and because of their biological importance. ${ }^{3}$ Indeed, naturally occurring porphyrins play essential roles in photosynthesis, cellular respiration and biological electron transfer reactions. ${ }^{3}$ Thus, considerable effort is devoted to design new materials that incorporate porphyrins as molecular building blocks in order to mimic natural systems. ${ }^{3-6}$ In particular, polynuclear porphyrins attract considerable interest owing to the possibility of energy or electron transfer between the macrocycles. Therefore, various strategies have been developed to synthesize porphyrin dimers (or oligomers).

Such dimers can be promoted for instance by electrostatic interactions, coordination interactions or covalent bonds. For example, electrostatic cofacial dimers have been obtained in aqueous solution between $\beta$-tetracationic and mesotetraanionic manganese(III) porphyrins. ${ }^{7}$ In the case of coordination bonds, two approaches can be envisaged. The first one consists in the axial coordination of the metal of one

${ }^{a}$ Laboratoire de Chimie Physique, UMR 8000 CNRS/Université Paris-Sud 11, Faculté des Sciences d'Orsay, Bâtiment 349, 91405 Orsay Cedex, France. E-mail: laurent.ruhlmann@u-psud.fr; Fax: + $33169156188 ;$ Tel: + 33169154438

${ }^{b}$ Institut des NanoSciences de Paris, UMR 7588 CNRS/Université Paris 6, 4 place Jussieu, boîte courrier 840, 75252 Paris Cedex 05, France

${ }^{c}$ Laboratoire d'Analyse et Contrôle des Systèmes Complexes, ECE Paris Ecole d'Ingénieurs, 37 quai de Grenelle, 75015 Paris, France

${ }^{d}$ Université Paris Descartes, 45 rue des Saint Pères, 75006 Paris, France

${ }^{e}$ Laboratoire d'Electrochimie et de Chimie-Physique du Corps Solide, UMR 7177 CNRS/Université de Strasbourg, 4 rue Blaise Pascal, CS 90032, 67081 Strasbourg Cedex, France porphyrin with a Lewis base (like a pyridyl group for example) substituted on the second porphyrin. ${ }^{8}$ The second approach corresponds to the formation of an oxo-bond between the metals of two porphyrins. ${ }^{9}$

Strategies allowing the formation of covalently linked porphyrin dimers are more numerous, and a large variety of linkages between the two macrocycles are permitted. For instance, Osuka and Shimidzu have proposed a strategy based on the chemical oxidation of porphines allowing a direct meso-meso coupling of the macrocycles. ${ }^{10}$ Another method consists in using an elementary brick containing the bridging spacer which is linked to four pyrroles. Afterwards, these pyrroles can be condensed to other compounds via aldehyde functions in order to form two macrocycles on both sides. ${ }^{1-13}$ But a more current strategy consists in using two porphyrins substituted by judicious groups allowing a coupling. For instance, the synthesis can be performed via metal-catalyzed reactions (Pd-catalyzed Sonogashira ${ }^{14}$ or Stille $^{15}$ coupling, Cu-catalyzed Ullmann ${ }^{16}$ coupling. . .).

In our precedent works, we have shown an electrochemical method based on a nucleophilic attack of a Lewis base containing two distinct nucleophilic sites which can react with electrogenerated radical cations of two porphyrins. This strategy has allowed us to synthesis porphyrin dimers with diphosphonium bridges ${ }^{17,18}$ or viologen spacers. ${ }^{19}$

Using a similar electrochemical process, we have taken porphyrins substituted by a pyridyl group which can also act as a Lewis base towards the electrogenerated radical cation of a second porphyrin. In this way, porphyrin dimers with a pyridinium spacer can be obtained. Many porphyrins bearing pyridinium units as substituents have already been studied in the literature and have shown interesting physical chemistry properties. ${ }^{20-23}$ Nevertheless, to our knowledge, it is the first 


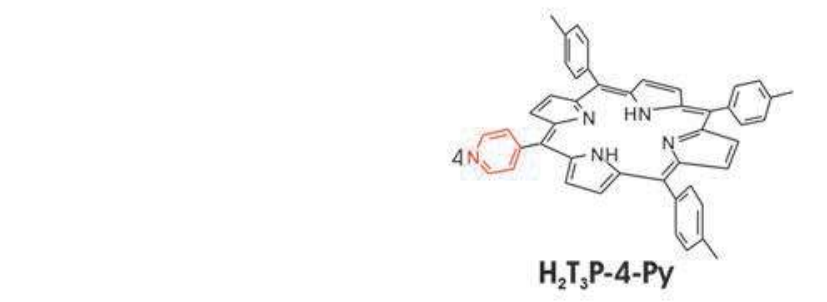

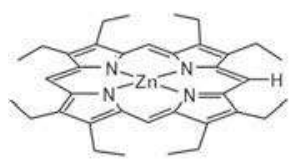
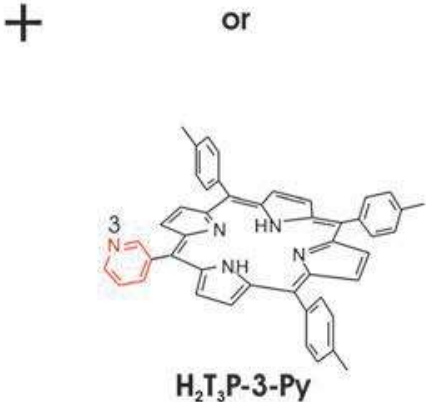

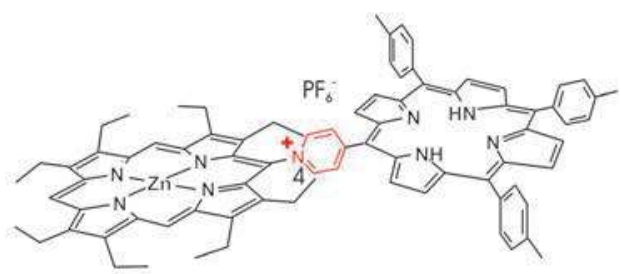

4- $\mathrm{H}_{2}-\mathrm{Zn}$

$+0.75 \mathrm{~V} / \mathrm{SCE}$ $\mathrm{NEt}_{4} \mathrm{PF}_{6} 0.1 \mathrm{M}$ $-2 e^{-}-\mathrm{H}^{+}$

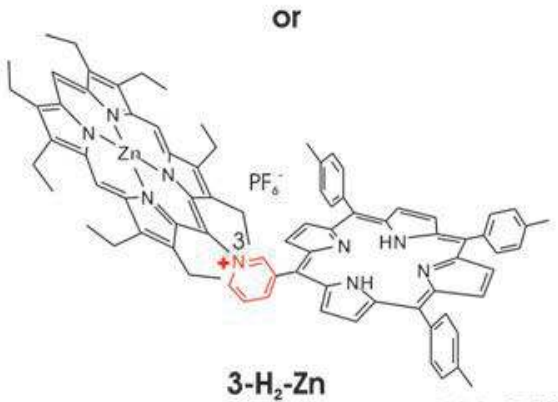

yield: $85 \%$

Scheme 1 Electrosynthesis scheme of the two dimers studied, $4-\mathrm{H}_{2}-\mathrm{Zn}$ and $3-\mathrm{H}_{2}-\mathrm{Zn}$.

example of porphyrin dimers with such a spacer. A pyridiniumtype spacer has the advantage of allowing a short distance between the two macrocycles. Moreover, this spacer could also permit interesting electronic coupling between the two porphyrins.

Thus, the present work reports on the synthesis of the first two dimers with a pyridinium spacer (abbreviated $4-\mathrm{H}_{2}-\mathrm{Zn}$ and $3-\mathrm{H}_{2}-\mathrm{Zn}$, Scheme 1). These dimers have been obtained from the zinc $\beta$-octaethylporphyrin (ZnOEP) and two isomers of the 5,10,15-tritolyl-20-pyridylporphyrin, where the pyridyl group is either in the para position $\left(\mathrm{H}_{2} \mathrm{~T}_{3} \mathrm{P}-4-\mathrm{Py}\right)$ or in the meta position $\left(\mathrm{H}_{2} \mathrm{~T}_{3} \mathrm{P}-3-\mathrm{Py}\right)$, respectively. Like this, the angle between the two macrocycles can be modulated.

\section{Results and discussion}

\section{Electrosynthesis}

It is well known that the oxidation of the $\pi$-ring of the porphyrins proceeds via two one-electron steps generating radical cations and dications. ${ }^{2,24,25}$

Prior to the electrosynthesis of the two dimers, the electrochemical behavior of the three used porphyrins has been investigated by cyclic voltammetry in $1,2-\mathrm{C}_{2} \mathrm{H}_{4} \mathrm{Cl}_{2}$. The first oxidation step of $\mathrm{H}_{2} \mathrm{~T}_{3} \mathrm{P}-4-\mathrm{Py}$ and $\mathrm{H}_{2} \mathrm{~T}_{3} \mathrm{P}-3-\mathrm{Py}$ is observed at 1.06 and $1.04 \mathrm{~V} / \mathrm{SCE}$, respectively, while for $\mathrm{ZnOEP}$, this first oxidation step is observed at a lower potential $(0.65 \mathrm{~V} / \mathrm{SCE}$, Table 1). Consequently, an exhaustive electrooxidation at $0.75 \mathrm{~V} / \mathrm{SCE}$ of a mixture of $\mathrm{ZnOEP}$ and one of the two pyridyl porphyrins $\left(\mathrm{H}_{2} \mathrm{~T}_{3} \mathrm{P}-4-\mathrm{Py}\right.$ or $\left.\mathrm{H}_{2} \mathrm{~T}_{3} \mathrm{P}-3-\mathrm{Py}\right)$ generates the radical cation of $\mathrm{ZnOEP}\left(\mathrm{ZnOEP}^{\bullet}\right)$ without oxidation of the other macrocycle. Thus, the pyridyl group of this porphyrin can react as a nucleophile with an electrochemically generated $\mathrm{ZnOEP}^{\bullet}{ }^{+}$, leading to the formation of a dimer.

During exhaustive electrolysis, the current decreases exponentially with time, and reaches the residual current (measured
Table 1 Electrochemical data for $\mathrm{ZnOEP}, \mathrm{H}_{2} \mathrm{~T} 3 \mathrm{P}-4-\mathrm{Py}, \mathrm{H}_{2} \mathrm{~T}_{3} \mathrm{P}-3-\mathrm{Py}$, $4-\mathrm{H}_{2}-\mathrm{Zn}$ and $3-\mathrm{H}_{2}-\mathrm{Zn}$

\begin{tabular}{|c|c|c|c|c|c|c|c|}
\hline \multirow[b]{2}{*}{ Compounds } & \multicolumn{3}{|c|}{ Oxidation } & \multicolumn{4}{|c|}{ Reduction } \\
\hline & Ring & & & $\mathrm{Py}^{+}$ & Ring & & \\
\hline ZnOEP & 1.04 & 0.65 & & & -1.59 & & \\
\hline $\mathrm{H}_{2} \mathrm{~T}_{3} \mathrm{P}-4-\mathrm{Py}$ & 1.30 & 1.06 & & & -1.14 & -1.43 & \\
\hline $\mathrm{H}_{2} \mathrm{~T}_{3} \mathrm{P}-3-\mathrm{Py}$ & 1.33 & 1.04 & & & -1.16 & -1.49 & \\
\hline $4-\mathrm{H}_{2}-\mathrm{Zn}$ & 1.59 & 1.24 & 0.95 & -0.75 & -1.17 & -1.49 & -1.69 \\
\hline $3-\mathrm{H}_{2}-\mathrm{Zn}$ & 1.47 & 1.22 & 0.90 & $-0.97^{\mathrm{irr}}$ & -1.26 & -1.59 & \\
\hline
\end{tabular}

All potentials in $\mathrm{V} v s$. SCE were obtained from cyclic voltammetry in 1,2- $\mathrm{C}_{2} \mathrm{H}_{4} \mathrm{Cl}_{2}$ containing $0.1 \mathrm{~mol} \mathrm{~L}^{-1} \mathrm{NBu}_{4} \mathrm{PF}_{6}$ at $100 \mathrm{mV} \mathrm{s}^{-1}$ (working electrode: glassy carbon). Bold characters are used for potential values observed for ZnOEP; italic characters are used for potential values observed for $\mathrm{H}_{2} \mathrm{~T}_{3} \mathrm{P}-x$-Py $(x=3$ or 4$)$ and underlined characters are used for pyridinium signals. irr: irreversible.

in the absence of electroactive compounds) after $c a .24 \mathrm{~h}$ for both the synthesized dimers. At the end of the electrolysis, the number of electrons transferred was 2.1 and 2.0 per molecule of $\mathrm{ZnOEP}$, for $4-\mathrm{H}_{2}-\mathrm{Zn}$ and $3-\mathrm{H}_{2}-\mathrm{Zn}$ respectively.

According to our precedent works, ${ }^{19}$ an $\mathrm{EC}_{\mathrm{N}} \mathrm{EC}_{\mathrm{B}}$ mechanism can be proposed to explain the formation of these dimers. In the first step, the radical cation $\mathrm{ZnOEP}^{\bullet}{ }^{+}$is electrochemically obtained by oxidation of the ZnOEP macrocycle (Scheme 2, step $\mathrm{E}_{1}$ ). Then, the pyridyl group of $\mathrm{H}_{2} \mathrm{~T}_{3} \mathrm{P}-x$-Py $(x=3$ or 4 ) can carry out a nucleophilic attack on this radical cation (Scheme 2, step $\mathrm{C}_{\mathrm{N}}$ ), leading to the formation of a dimer for which the ZnOEP macrocycle leads to an isoporphyrin. This isoporphyrin corresponds to a porphyrin for which the aromaticity is broken, because of the simultaneous presence of a pyridinium group and a proton on the same meso carbon. Afterwards, this isoporphyrin can be oxidized again (Scheme 2, step $\mathrm{E}_{2}$ ). Finally, this spare proton is lost, leading to the rearomaticity of the $\mathrm{ZnOEP}$ macrocycle 

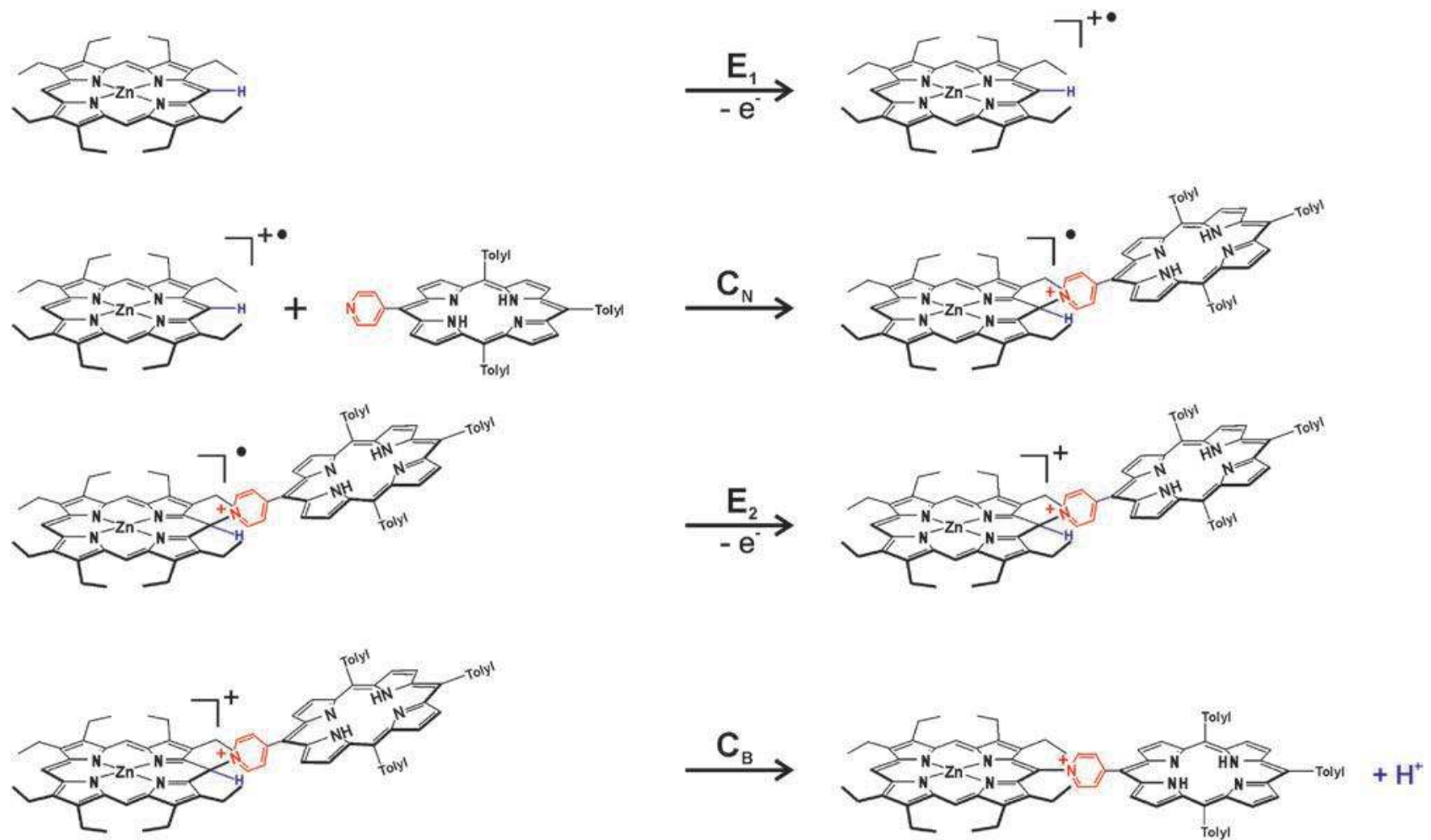

Scheme 2 Mechanistic scheme for the electrosynthesis of the 4- $\mathrm{H}_{2}-\mathrm{Zn}$ dimer. A similar mechanism can also be proposed for the formation of $3-\mathrm{H}_{2}-\mathrm{Zn}$.

(Scheme 2, step $\mathrm{C}_{\mathrm{B}}$ ). Thus the global reaction can be summarised like this:

$$
\begin{gathered}
\text { ZnOEP }+\mathrm{H}_{2} \mathrm{~T}_{3} \mathrm{P}-x \text {-Py } \\
\rightarrow \mathrm{H}_{2} \mathrm{~T}_{3} \mathrm{P}-x-\mathrm{Py}^{+}-\mathrm{ZnOEP}+2 \mathrm{e}^{-}+\mathrm{H}^{+} \quad(x=3 \text { or } 4)
\end{gathered}
$$

After electrolysis for $24 \mathrm{~h}$ at $0.75 \mathrm{~V} / \mathrm{SCE}$, the initial red solution turned brown. The purified $\mathrm{H}_{2} \mathrm{~T}_{3} \mathrm{P}-x-\mathrm{Py}{ }^{+}-\mathrm{ZnOEP}$ (abbreviated $x-\mathrm{H}_{2}-\mathrm{Zn}, x=3$ and 4 ) are obtained with a yield of 87 and $85 \%$, respectively.

It is to be noted that the applied potential $(0.75 \mathrm{~V} / \mathrm{SCE})$ is too low to permit multi-substitutions of $\mathrm{H}_{2} \mathrm{~T}_{3} \mathrm{P}-x$-Py $(x=3$ or 4 ) on the $\mathrm{ZnOEP}$ macrocycle. Indeed, the first oxidation potential of the mono-substituted ZnOEP is higher than that for the non-substituted $\mathrm{ZnOEP}$, because of the electron-withdrawing effect of the pyridinium group on the $\mathrm{ZnOEP}$ macrocycle (see below).

Of course, we have also tried to synthesize the dimer $\mathrm{H}_{2} \mathrm{~T}_{3} \mathrm{P}-$ 2-Py ${ }^{+}-\mathrm{ZnOEP}$ from the $\mathrm{H}_{2} \mathrm{~T}_{3} \mathrm{P}-2$-Py macrocycle bearing the pyridyl group in the ortho position. Nevertheless, a mixture of several products has been obtained, with a small yield besides. The poor reactivity can be explained by an important steric hindrance. Moreover, this steric hindrance can also lead to a drastic decrease of the rate of the nucleophilic attack of the pyridyl group onto the electrogenerated radical cation of the $\mathrm{ZnOEP}$. Nevertheless, the radical cation $\mathrm{ZnOEP}^{\bullet}{ }^{+}$is too reactive to remain stable for a long time, and consequently, can react further with small traces of water present in the organic solvent, ${ }^{26}$ leading to degradation of products.

\section{HR-MS spectra}

The dimers $4-\mathrm{H}_{2}-\mathrm{Zn}$ and $3-\mathrm{H}_{2}-\mathrm{Zn}$ have been characterized by HR-MS mass spectroscopy. The mass spectrum of the molecular ion region corresponds to the theoretical isotopic pattern for $[\mathrm{M}]^{+}$as shown in Fig. 1 in the case of $3-\mathrm{H}_{2}-\mathrm{Zn}$. The mass spectrum gives $[\mathrm{M}]^{+}$at $m / z$ 1252.5666. This supports the

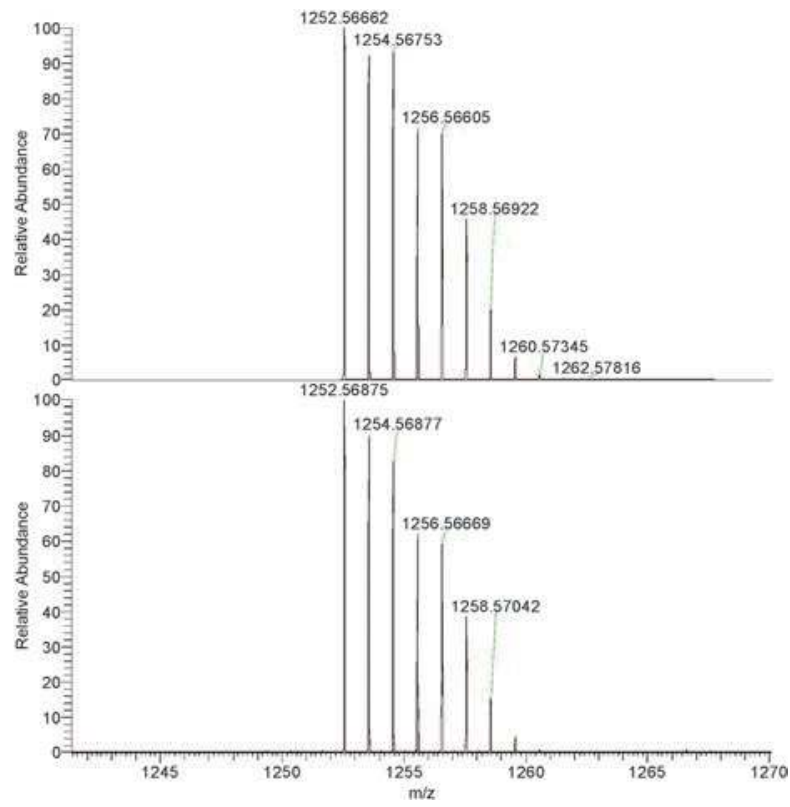

Fig. 1 Obtained (top) and predicted (bottom) HR-MS data for $3-\mathrm{H}_{2}-\mathrm{Zn}$. 
notion that compound $3-\mathrm{H}_{2}-\mathrm{Zn}$ is indeed prepared as $m / z$ calculated for the dimer, $\left[\mathrm{ZnC}_{82} \mathrm{H}_{78} \mathrm{~N}_{9}{ }^{+}\right]$(1252.5688). Similar data are obtained for $4-\mathrm{H}_{2}-\mathrm{Zn}$.

\section{${ }^{1}$ H NMR spectra}

${ }^{1} \mathrm{H}$ NMR spectroscopy of the two dimers has been carried out in $\left(\mathrm{CD}_{3}\right)_{2} \mathrm{CO}$. Complete NMR data are reported in the Experimental section. For each dimer, the observation of two singlets in the range of $10.30-10.55 \mathrm{ppm}$, which are integrated with a ratio equal to $1: 2$ and which are attributed to the meso-H protons, is consistent with the proposed mono-substitution in a meso position of the ZnOEP. In the range of 9.50-11.35 ppm, supplementary signals are attributed to the protons of the pyridinium groups. Indeed, two doublets (with integrations of two protons for each of them) are present in the case of the compound $4-\mathrm{H}_{2}-\mathrm{Zn}$, whereas four signals (with integrations of one proton for each) are observed for the dimer $3-\mathrm{H}_{2}-\mathrm{Zn}$. In the range of 8.90-9.45 ppm are present three signals (two doublets and one singlet) attributed to the $\beta-\mathrm{H}$ protons of the $\mathrm{H}_{2} \mathrm{~T}_{3} \mathrm{P}-4-\mathrm{Py}$ or $\mathrm{H}_{2} \mathrm{~T}_{3} \mathrm{P}-3$-Py porphyrin unit. The singlet is assigned to the four $\beta-\mathrm{H}$ protons farthest from the pyridinium group and the two doublets, more deshielded, are assigned to the four $\beta-\mathrm{H}$ protons closest to the pyridinium group. Moreover, in the aromatic part, the signals assigned to the protons corresponding to the tolyl groups of the $\mathrm{H}_{2} \mathrm{~T}_{3} \mathrm{P}-4-\mathrm{Py}$ or $\mathrm{H}_{2} \mathrm{~T}_{3} \mathrm{P}-3$-Py porphyrin are observed in the range of $7.60-8.30 \mathrm{ppm}$. Concerning the ethyl protons of $\mathrm{ZnOEP}$ units and the methyl protons of the tolyl groups of the other porphyrin, they are observed in the shielded part, between 1 and $4.5 \mathrm{ppm}$. The methyl protons of the tolyl are present at ca. 2.66-2.67 ppm. Finally, the inner $\mathrm{N}-\mathrm{H}$ protons of the $\mathrm{H}_{2} \mathrm{~T}_{3} \mathrm{P}-4-\mathrm{Py}$ or $\mathrm{H}_{2} \mathrm{~T}_{3} \mathrm{P}-3$-Py porphyrin appear at $c a .-2.5 \mathrm{ppm}$ as a singlet. This singlet suggests that $\mathrm{N}-\mathrm{H}$ tautomerization is rapid in comparison to the NMR time scale. ${ }^{27}$

\section{UV-vis absorption and fluorescence spectra}

The UV-vis absorption spectra of the dimers (Fig. 2A and B) do not correspond to the mere addition of the spectra of the corresponding individual porphyrins.

Indeed, the Soret band of each dimer appears split, due to the presence of the two different porphyrins, but a red-shift of the Soret and Q bands ( $c a .5 \mathrm{~nm}$ ) is also observed compared to that for the porphyrins alone, in particular for the ZnOEP. This red-shift can be explained by an electron-withdrawing effect of the pyridinium spacer. ${ }^{22,23}$ This splitting is accompanied by a broadening of the absorption bands, which suggests also excitonic interactions between the two porphyrin rings. ${ }^{19}$ In the case of $4-\mathrm{H}_{2}-\mathrm{Zn}$, a broad band around $440-480 \mathrm{~nm}$ is observed. This band may characterize a partial delocalization of the positive charge of the pyridinium onto the ZnOEP macrocycle leading to the red-shift. Such an additional band is not due to the partial protonation of the free base macrocycle of the dimer (possible presence of an acid trace in $1,2-\mathrm{C}_{2} \mathrm{H}_{4} \mathrm{Cl}_{2}$ due to the degradation of the solvent under light illumination). Indeed, no change is observed after the addition of an excess of base such as 2,6-lutidine. Such a delocalisation is less or not observed in the case of $3-\mathrm{H}_{2}-\mathrm{Zn}$.

Concerning the fluorescence spectra (Fig. 3), a total quenching of the luminescence is observed for both porphyrins within
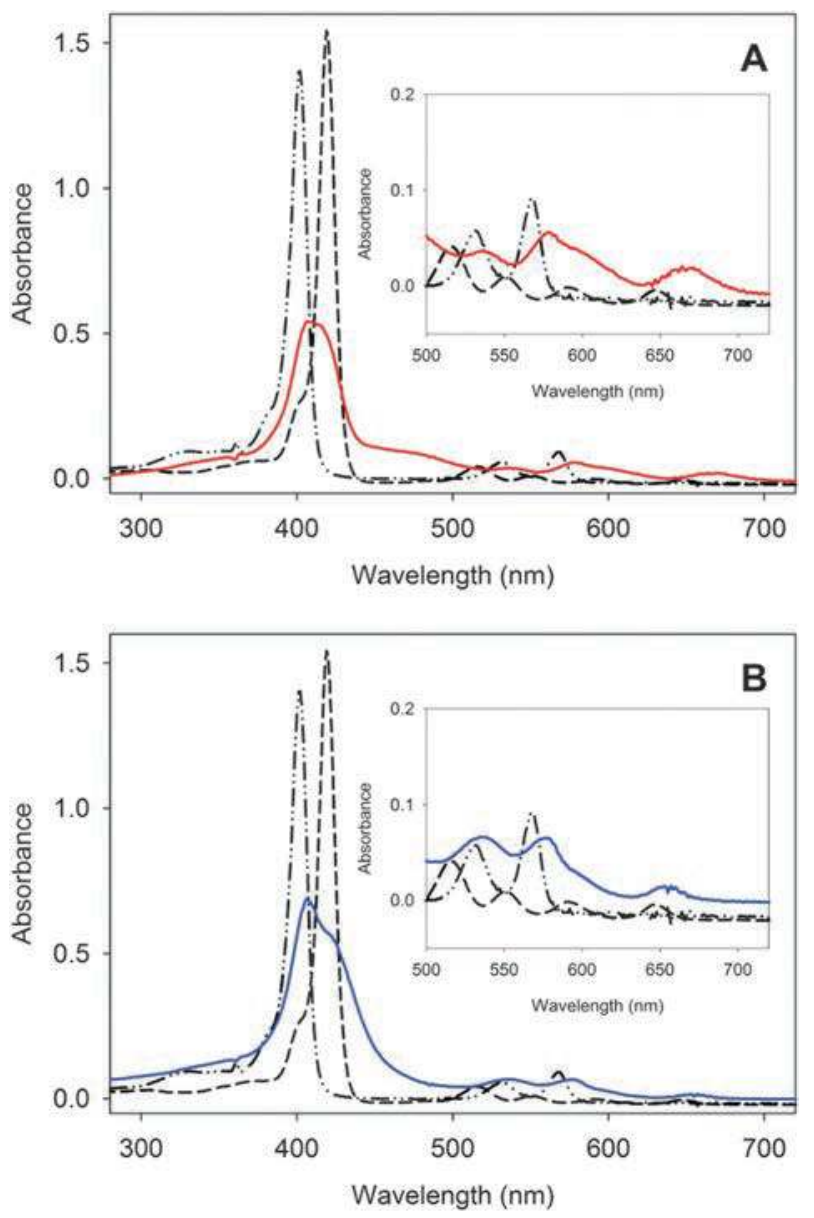

Fig. 2 UV-vis absorption spectra of $\mathrm{H}_{2} \mathrm{~T}_{3} \mathrm{P}-4-\mathrm{Py}$ and $\mathrm{H}_{2} \mathrm{~T}_{3} \mathrm{P}-3-\mathrm{Py}$ $\left(c=5 \times 10^{-6} \mathrm{~mol} \mathrm{~L}^{-1}\right.$, dashed line), $\mathrm{ZnOEP}\left(c=5 \times 10^{-6} \mathrm{~mol} \mathrm{~L}^{-1}\right.$, dash-dotted line) and (A) 4- $\mathrm{H}_{2}-\mathrm{Zn}\left(c=5 \times 10^{-6} \mathrm{~mol} \mathrm{~L}^{-1}\right.$, full line) and (B) $3-\mathrm{H}_{2}-\mathrm{Zn}\left(c=5 \times 10^{-6} \mathrm{~mol} \mathrm{~L} \mathrm{~L}^{-1}\right.$, full line $)$ in $1,2-\mathrm{C}_{2} \mathrm{H}_{4} \mathrm{Cl}_{2}$ ( $1 \mathrm{~cm}$ path length cell). Inset: zoom of the $\mathrm{Q}$ bands.

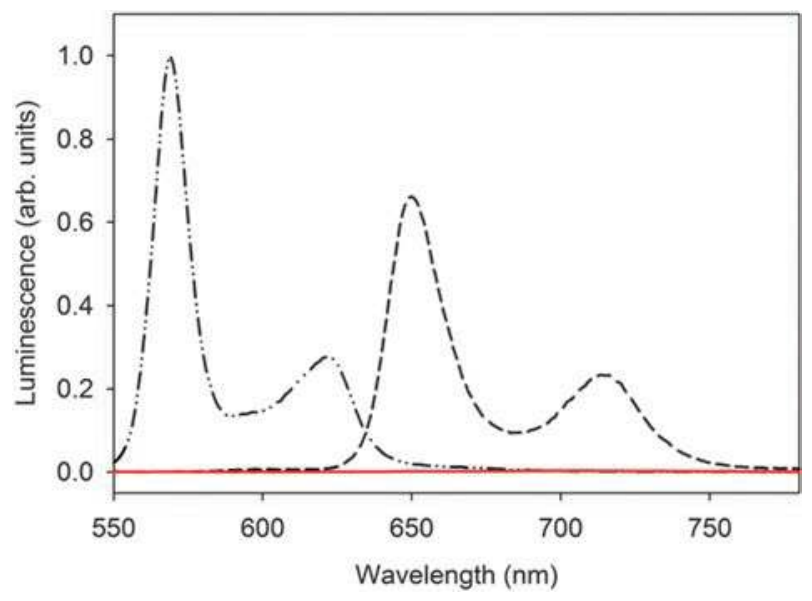

Fig. 3 Fluorescence spectra of 4- $\mathrm{H}_{2}-\mathrm{Zn}$ (full line), $\mathrm{H}_{2} \mathrm{~T}_{3} \mathrm{P}-4-\mathrm{Py}$ (dashed line) and $\mathrm{ZnOEP}$ (dash-dotted line) in $1,2-\mathrm{C}_{2} \mathrm{H}_{4} \mathrm{Cl}_{2}$ (excitation wavelength: $530 \mathrm{~nm}$ ). A similar behaviour is observed by comparison of $3-\mathrm{H}_{2}-\mathrm{Zn}$ with $\mathrm{H}_{2} \mathrm{~T}_{3} \mathrm{P}-3$-Py and $\mathrm{ZnOEP}$.

the dimers. This result can be ascribed to rapid electron transfer from the excited porphyrins to the pyridinium acceptor. $^{23,28}$ 


\section{Electrochemistry}

The electrochemical behaviour of free base porphyrins and metalloporphyrins involving nonelectroactive metals is well documented. ${ }^{2}$ In general, in the anodic domain, the oxidation of the $\pi$-ring proceeds via two one-electron steps generating radical cations and dications. Similarly, in the cathodic domain, two one-electron steps yield radical anions and dianions.

The potential values of these redox processes attributed to the three porphyrins and the two dimers are gathered in Table 1.

Fig. 4 illustrates the $\mathrm{CV}$ curves recorded for the $3-\mathrm{H}_{2}-\mathrm{Zn}$ dimer. In the anodic part, three successive quasi reversible processes can be observed at $0.90,1.22$ and $1.47 \mathrm{~V} / \mathrm{SCE}$ (Table 1 and Fig. 4). The first one could be attributed to the first oxidation of the $\mathrm{ZnOEP}$ ring, the second one both to the first oxidation of the $\mathrm{H}_{2} \mathrm{~T}_{3} \mathrm{P}-3-\mathrm{Py}$ ring and the second oxidation of the $\mathrm{ZnOEP}$ ring, and the last one to the second oxidation of the $\mathrm{H}_{2} \mathrm{~T}_{3} \mathrm{P}-3-\mathrm{Py}$ ring. Compared to the potential values recorded for the corresponding unsubstituted monomers of porphyrins, these oxidation potentials are shifted about $150-250 \mathrm{mV}$. These shifts may be ascribed to the electronwithdrawing effect of the positively charged pyridinium on the $\pi$ systems of the porphyrins. ${ }^{19,22,29}$

Concerning the cathodic part, three successive processes can be also observed at $-0.97,-1.26$ and $-1.59 \mathrm{~V} / \mathrm{SCE}$ (Table 1
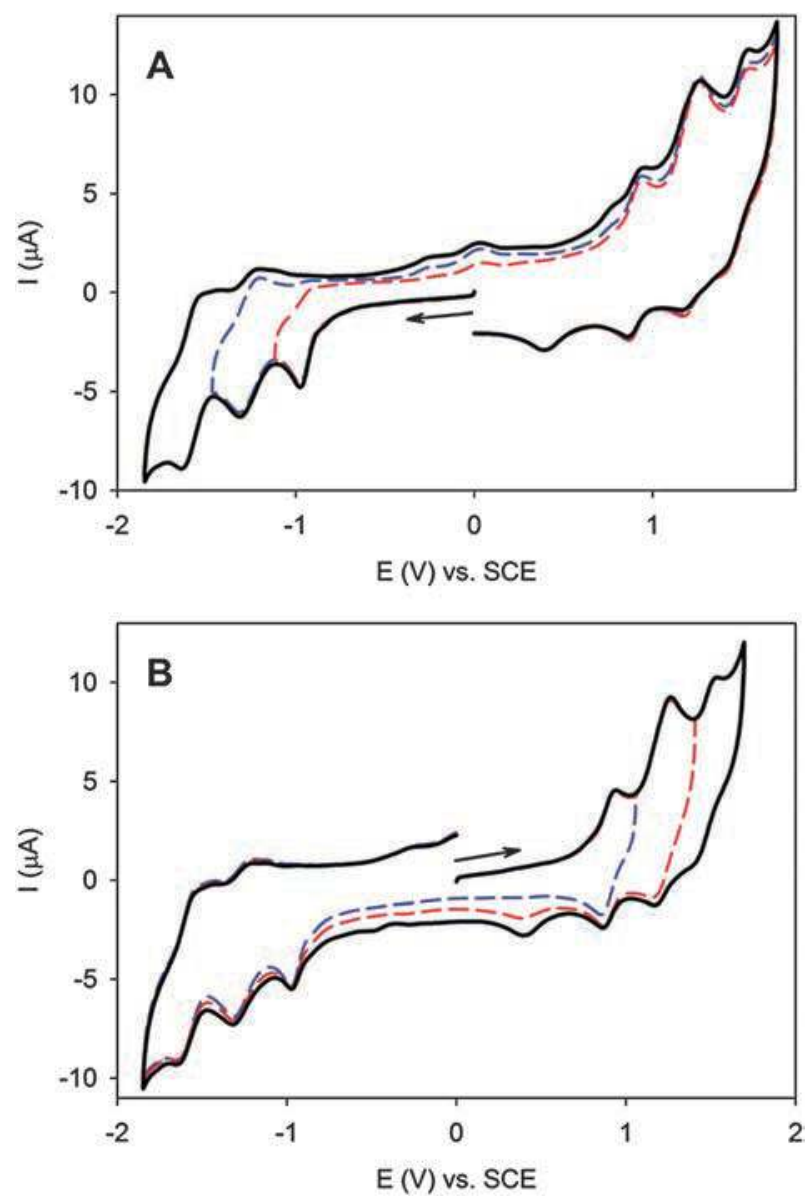

Fig. $4 \mathrm{CVs}$ for $3-\mathrm{H}_{2}-\mathrm{Zn}\left(c=2.5 \times 10^{-4} \mathrm{~mol} \mathrm{~L}^{-1}\right)$ in $1,2-\mathrm{C}_{2} \mathrm{H}_{4} \mathrm{Cl}_{2}$ containing $0.1 \mathrm{~mol} \mathrm{~L}^{-1} \mathrm{NBu}_{4} \mathrm{PF}_{6}$ at $100 \mathrm{mV} \mathrm{s}^{-1}$ (working electrode: glassy carbon). (A) First cathodic scan. (B) First anodic scan.

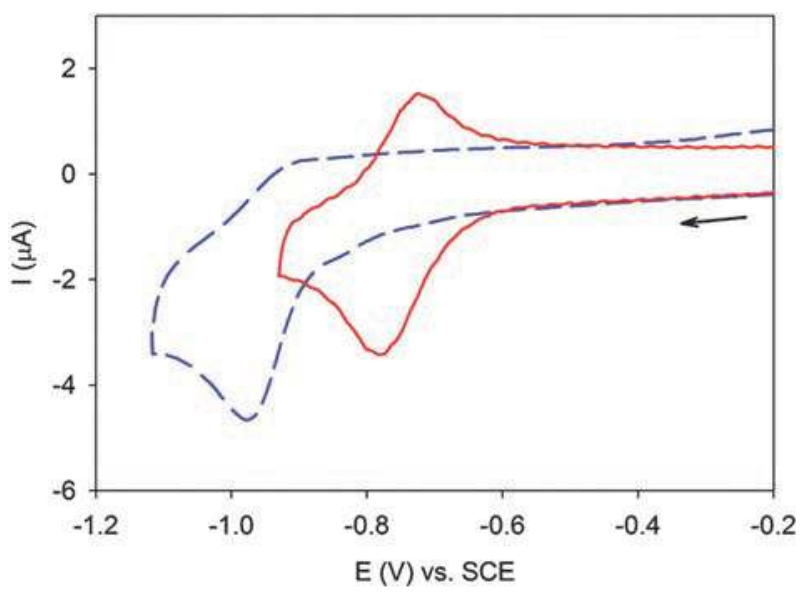

Fig. 5 Cathodic wave corresponding to the reduction of the $\mathrm{Py}^{+}$spacer for $4-\mathrm{H}_{2}-\mathrm{Zn}$ (full line) and $3-\mathrm{H}_{2}-\mathrm{Zn}$ (dashed line) in $1,2-\mathrm{C}_{2} \mathrm{H}_{4} \mathrm{Cl}_{2}$ containing $0.1 \mathrm{~mol} \mathrm{~L}^{-1} \mathrm{NBu}_{4} \mathrm{PF}_{6}$ at $100 \mathrm{mV} \mathrm{s}^{-1}$ (working electrode: glassy carbon).

and Fig. 4). The first wave is quasi irreversible while the two last waves are reversible. The first quasi irreversible process at $-0.97 \mathrm{~V} / \mathrm{SCE}$ could be assigned to the reduction of the pyridinium spacer whereas the second and the third processes could be attributed to the reduction of the macrocycles (reduction of the $\mathrm{H}_{2} \mathrm{~T}_{3} \mathrm{P}-3-\mathrm{Py}$ ring at $-1.26 \mathrm{~V}$ and simultaneous reduction of the $\mathrm{H}_{2} \mathrm{~T}_{3} \mathrm{P}-3-\mathrm{Py}$ and $\mathrm{ZnOEP}$ rings at $-1.59 \mathrm{~V})$. In contrast to the oxidation waves, the reduction processes are not significantly shifted compared to the unsubstituted porphyrins. This can be explained by the fact that the pyridinium spacer is reduced in a first step, leading to a neutral dimeric compound.

Similar behaviours are observed for the $4-\mathrm{H}_{2}-\mathrm{Zn}$ dimer (Table 1), except concerning the reduction process of the pyridinium spacer (Fig. 5). Indeed, while this electronic transfer was quasi irreversible in the case of $3-\mathrm{H}_{2}-\mathrm{Zn}$, a reversible wave is observed at $-0.75 \mathrm{~V} / \mathrm{SCE}$ for $4-\mathrm{H}_{2}-\mathrm{Zn}$. Consequently, the pyridyl radical generated from the reduction of the pyridinium group appears more stable for the $4-\mathrm{H}_{2}-\mathrm{Zn}$ dimer than for the other dimer.

We can also note an important change in the potential values for the pyridinium reduction for these two dimers. Indeed, the pyridinium of the $4-\mathrm{H}_{2}-\mathrm{Zn}$ compound is more easily reduced $(-0.75 \mathrm{~V} / \mathrm{SCE})$ than that of the $3-\mathrm{H}_{2}-\mathrm{Zn}$ compound $(-0.97 \mathrm{~V} / \mathrm{SCE})$. This observation might be also tentatively explained by a most important increase in stability of the radical for the $4-\mathrm{H}_{2}-\mathrm{Zn}$ dimer, this increase of stability being in favour of an easier reduction.

\section{Spectroelectrochemistry}

Spectroelectrochemical studies have been carried out on the first reduction and the first and second oxidations under the same experimental conditions as the electrochemical measurements (i.e. in 1,2- $\mathrm{C}_{2} \mathrm{H}_{4} \mathrm{Cl}_{2}$ containing $0.1 \mathrm{~mol} \mathrm{~L}{ }^{-1} \mathrm{NBu}_{4} \mathrm{PF}_{6}$ ). The optical absorption spectra of the systems studied can be used as an additional support for the assignments of the observed redox steps.

For $4-\mathrm{H}_{2}-\mathrm{Zn}$, the spectral changes recorded during electrolysis at the first reduction wave at $-0.75 \mathrm{~V}$ are illustrated 

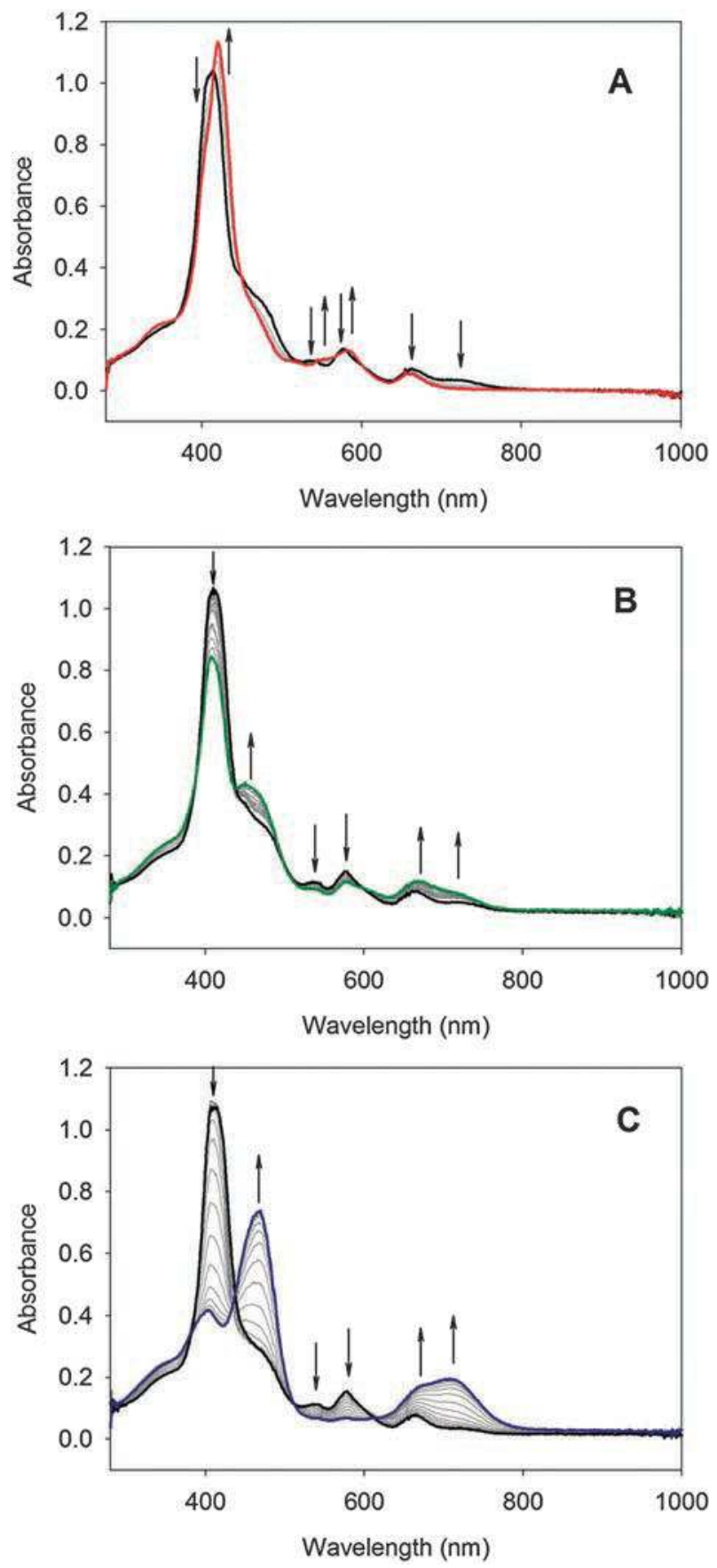

Fig. 6 Evolution of the UV-vis absorption spectrum of $4-\mathrm{H}_{2}-\mathrm{Zn}$ in 1,2- $\mathrm{C}_{2} \mathrm{H}_{4} \mathrm{Cl}_{2}$ containing $0.1 \mathrm{~mol} \mathrm{~L} \mathrm{~L}^{-1} \mathrm{NBu}_{4} \mathrm{PF}_{6}$ recorded during (A) reduction at $-0.74 \mathrm{~V},(\mathrm{~B})$ oxidation at $0.95 \mathrm{~V}$ and (C) oxidation at $1.24 \mathrm{~V}$ vs. $\mathrm{Ag} \mid \mathrm{AgCl}$.

in Fig. 6A. From our voltammetric measurements, this potential has been assigned to the reduction step of the pyridinium spacer. The reduction product exhibits a typical porphyrin spectrum profile with a red-shift of the Soret band by $c a .14 \mathrm{~nm}$ when compared to the parent compound. This result indicates that the electrons are not transferred to the porphyrin macrocycle but to the pyridinium cation and confirms our primary assignment. The initial broad band around 440-480 nm disappears during the reduction of the spacer showing that the partial delocalization of the positive charge of the pyridinium onto the ZnOEP macrocycle does not still occur. Examination of the UV-vis spectrum recorded after the first reduction step involving the pyridinium spacer in the case of $3-\mathrm{H}_{2}-\mathrm{Zn}$ shows also a red-shift for the Soret band ( $c a .11 \mathrm{~nm})$. However, a blue-shift attributed to the loss of the pyridinium (loss of the electron-withdrawing effect during the reduction of the spacer) is usually observed. Nevertheless, such an unusual red-shift was already noticed for the pyridinium reduction of $\mathrm{H}_{2} \mathrm{TPP}(\mathrm{Py})^{+}$, $\mathrm{ZnTPP}(\mathrm{Py})^{+}, \mathrm{ZnOEP}(\mathrm{Py})^{+}$and $\mathrm{ZnOEP}(\mathrm{Py})_{4}^{4+} .^{22,32}$ This redshift during electrolysis at the pyridinium reduction can be tentatively explained by a fast protonation of the pyridyl radical (obtained after the reduction of the pyridinium) which would maintain the overall positive charge of the molecule. Such a protonation is a common reaction with basic radicals even in nonaqueous media, and has been already described in the case of pyridinium reductions. ${ }^{30,31,33-35}$

For $4-\mathrm{H}_{2}-\mathrm{Zn}$, the spectral changes recorded during electrolysis at the first and second oxidation waves at $0.95 \mathrm{~V}$ and $1.24 \mathrm{~V}$ are illustrated in Fig. $6 \mathrm{~B}$ and $\mathrm{C}$. The first oxidation reveals a slight decrease in the intensity of the Soret band, which appears less important than that usually observed in the generation of porphyrin cation radicals. This can be tentatively explained by the decrease of the excitonic interactions between the two macrocycles during the oxidation of the metalloporphyrin subunit. Thus, the usual decrease of the intensity of the Soret band of $\mathrm{ZnOEP}^{\bullet}+$ can be compensated by an increase of the intensity of the free base. For $3-\mathrm{H}_{2}-\mathrm{Zn}$ similar behavior has been obtained.

Examination of the UV-vis spectrum recorded after the second oxidation step shows a new decrease in the intensity of the Soret band accompanied by an increase in the intensity of a new band at $470 \mathrm{~nm}$ and $451 \mathrm{~nm}$ for $4-\mathrm{H}_{2}-\mathrm{Zn}$ and $3-\mathrm{H}_{2}-\mathrm{Zn}$, respectively. This new Soret band is in agreement with the formation of diprotonated $\mathrm{H}_{4} \mathrm{~T}_{3} \mathrm{P}^{2+}$-Py macrocycles, respectively, 4- $\mathrm{H}_{4}^{2+}-\mathrm{Zn}$ and $3-\mathrm{H}_{4}^{2+}-\mathrm{Zn}$. Similarly, the intensity of the initial $\mathrm{Q}$ bands decreases with an increase in new $Q$ band(s) at $673 \mathrm{~nm}$ and $712 \mathrm{~nm}$ for $4-\mathrm{H}_{4}^{2+}-\mathrm{Zn}$ and $670 \mathrm{~nm}$ for $3-\mathrm{H}_{4}^{2+}-\mathrm{Zn}$, typical also of the formation of diprotonated species. Apparently, this band has already emerged during the first oxidation because of the applied potential used (close to the beginning of the second wave). These results indicate that the second oxidation wave of the dimer corresponds to the oxidation of the free base. This is in agreement with our previous assignments, since from the voltammetric measurements, we have attributed this second wave simultaneously to the second oxidation of $\mathrm{ZnOEP}$ and the first oxidation of the free base. Indeed, in contrast to metalloporphyrins with non-electroactive metal centres, the $\pi$ radical cations of porphyrin free bases are very reactive and can further react with the solvent or the supporting electrolyte via proton abstraction to give the diprotonated porphyrin, as already reported by Guilard et al. ${ }^{36}$ According to these authors, a radical reaction occurs, which can be written as follows:

$$
\begin{aligned}
& \mathrm{H}_{2} \mathrm{~T}_{3} \mathrm{P}-x-\mathrm{Py} \rightarrow \mathrm{H}_{2} \mathrm{~T}_{3} \mathrm{P}^{\bullet+}-x-\mathrm{Py}+\mathrm{e}^{-} \\
2 \mathrm{H}_{2} \mathrm{~T}_{3} \mathrm{P}^{\bullet+}-x-\mathrm{Py}+2 \mathrm{~S}-\mathrm{H} & \\
\rightarrow & \mathrm{H}_{4} \mathrm{~T}_{3} \mathrm{P}^{2+}-x-\mathrm{Py}+\mathrm{H}_{2} \mathrm{~T}_{3} \mathrm{P}-x-\mathrm{Py}+2 \mathrm{~S}^{\bullet}
\end{aligned}
$$

where the substrate $\mathrm{S}-\mathrm{H}$ can represent the solvent or the supporting electrolyte. 
Formation of a "tetramer" resulting from the coupling between two reduced $3-\mathrm{H}_{2}-\mathrm{Zn}$ dimers

As already reported below, the pyridyl radical appears less stable in the case of $3-\mathrm{H}_{2}-\mathrm{Zn}$, so it must be more reactive. Thus we can suggest a coupling in the 4-position of two pyridyl radicals yielding a "tetramer" of porphyrins (Scheme 3A). Indeed, the dimerization of pyridyl radicals when the 2-, 4- or 6-positions are free has been often discussed in the literature. ${ }^{22,23,30-32}$ This dimerization can be explained by the delocalisation possibilities of the radical onto the pyridyl group, which can take place only in positions 2, 4 and 6. Regarding the $4-\mathrm{H}_{2}-\mathrm{Zn}$ compound, the 4-position of the pyridyl radical is not free. Moreover the 2- and 6-positions seem to be too encumbered to allow a radical coupling dimerization. Furthermore, the presence of the tritolylporphyrin in the 4-position allows supplementary delocalisations of the radical onto this macrocycle (Scheme 3B), increasing even more the stability of this radical. Concerning the $3-\mathrm{H}_{2}-\mathrm{Zn}$ dimer, the 4-position is free, and consequently, the pyridyl radical is able to dimerize allowing the formation of a "tetramer" of porphyrins.

To support this hypothesis of reactivity of the pyridyl radical in the case of the $3-\mathrm{H}_{2}-\mathrm{Zn}$ dimer, we have carried out a steady state polarization at a potential equal to $-1.1 \mathrm{~V} / \mathrm{SCE}$ in $\mathrm{CH}_{3} \mathrm{CN}$, in order to reduce the pyridinium spacer. After that, further sweep reveals a new well defined oxidation peak (Fig. 7A) characteristic of the oxidation of the product resulting from the coupling (i.e. oxidation of the dipyridyl spacer ${ }^{22}$ of the "tetramer" of porphyrins) which coats the working electrode (the "tetramer" being not very soluble in $\mathrm{CH}_{3} \mathrm{CN}$ ) whose color becomes brown. When the deposition time $\left(t_{\mathrm{D}}\right)$ increases, the intensity of this peak becomes also more important, showing a greater amount of the "tetramer" of porphyrins formed. Moreover, this peak shifts anodically when the deposition time increases. This can be tentatively explained by the formation of aggregates on the electrodes with strong $\pi-\pi$ interactions between either the macrocycles or the dipyridyl spacers. In such a case, the anodic peak shift for the oxidation of the dipyridyl spacer, with the deposition time, can be explained by a greater stabilization of these dipyridyl spacers due to their aggregation by $\pi$-stacking. Indeed, the more the aggregates are important, the more the dipyridyl spacers are stabilized by $\pi$-stacking, and consequently the more they must be harder to oxidize. Nevertheless, this first oxidation peak assigned to the oxidation of the dipyridyl spacers leads to their breakage. Consequently, the initial $3-\mathrm{H}_{2}-\mathrm{Zn}$ dimers with pyridinium spacers are again obtained. Thus, this oxidation leads to the disorganisation and disappearance of the aggregates, and consequently, further peaks are not affected (no shift observed).

The morphology of the deposits has also been scrutinized by atomic force microscopy (Fig. 7C): whatever the deposition time, the deposits appear in the form of tightly packed coils (diameter around $50-80 \mathrm{~nm}$ ) which seem agglomerated in a binder. This result is also in favour of the formation of aggregates where $\pi-\pi$ interactions lead to the formation of coils.

A similar experiment has been performed with $4-\mathrm{H}_{2}-\mathrm{Zn}$. But in this case, no new anodic peak appears in the $\mathrm{CV}$ curve after

\section{A) $3-\mathrm{H}_{2}-\mathrm{Zn}$}

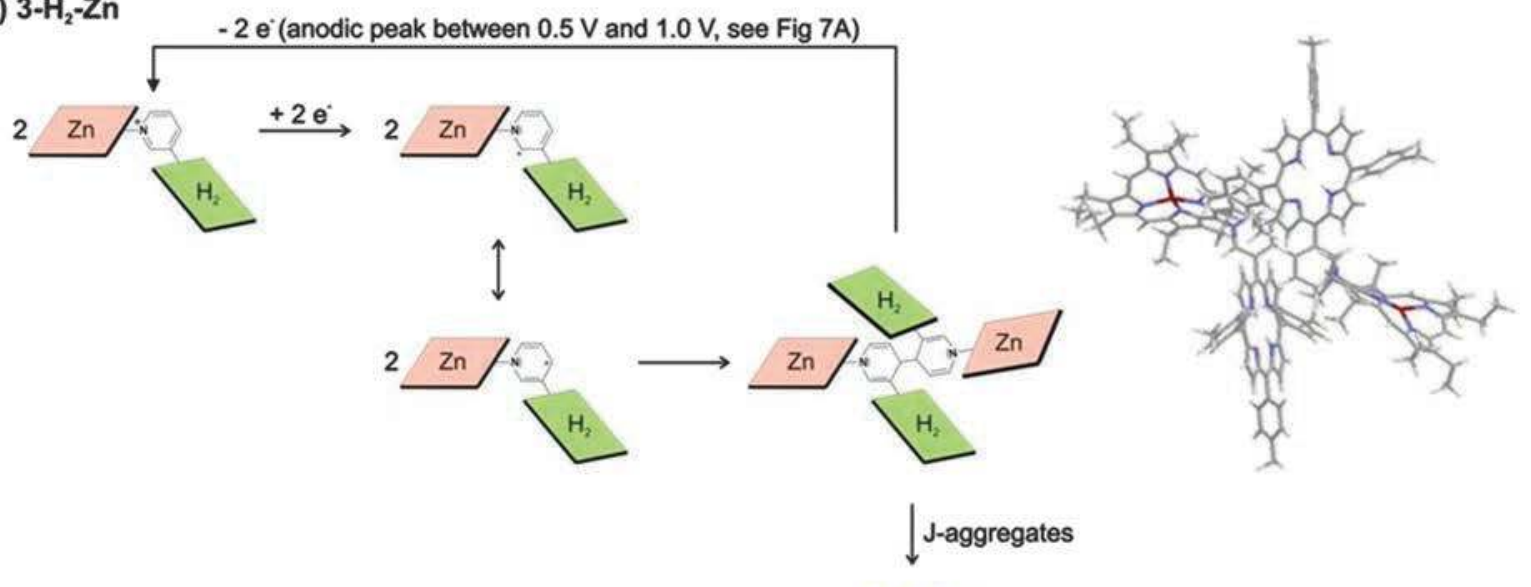

B) $4-\mathrm{H}_{2}-\mathrm{Zn}$

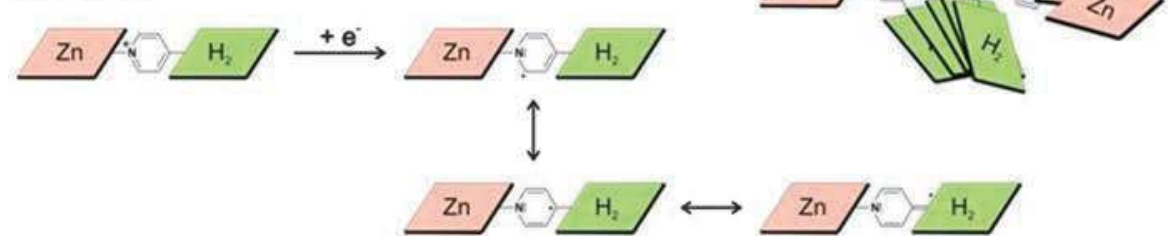

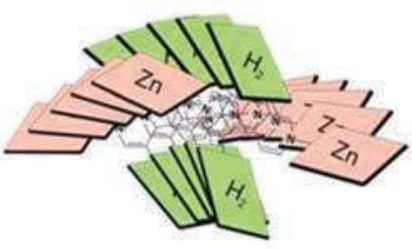

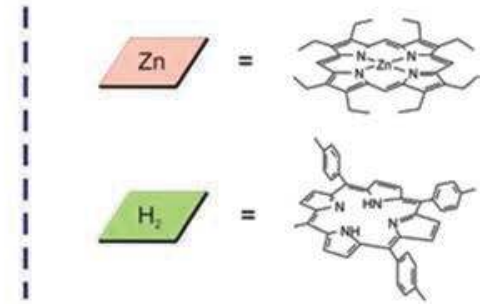

Scheme 3 (A) Electrochemical coupling mechanism proposed upon reduction of pyridinium for the 3- $\mathrm{H}_{2}-\mathrm{Zn}$ compound. The $3 \mathrm{D}$ structure of the tetramer has been obtained by the MM2 force field method. Tentative representation of the formation of aggregates of the tetramer on the electrodes via strong $\mathrm{p}-\mathrm{p}$ interactions. (B) Delocalization possibilities of the radical onto the pyridyl group in the case of the 4- $\mathrm{H}_{2}-\mathrm{Zn}$ compound. 

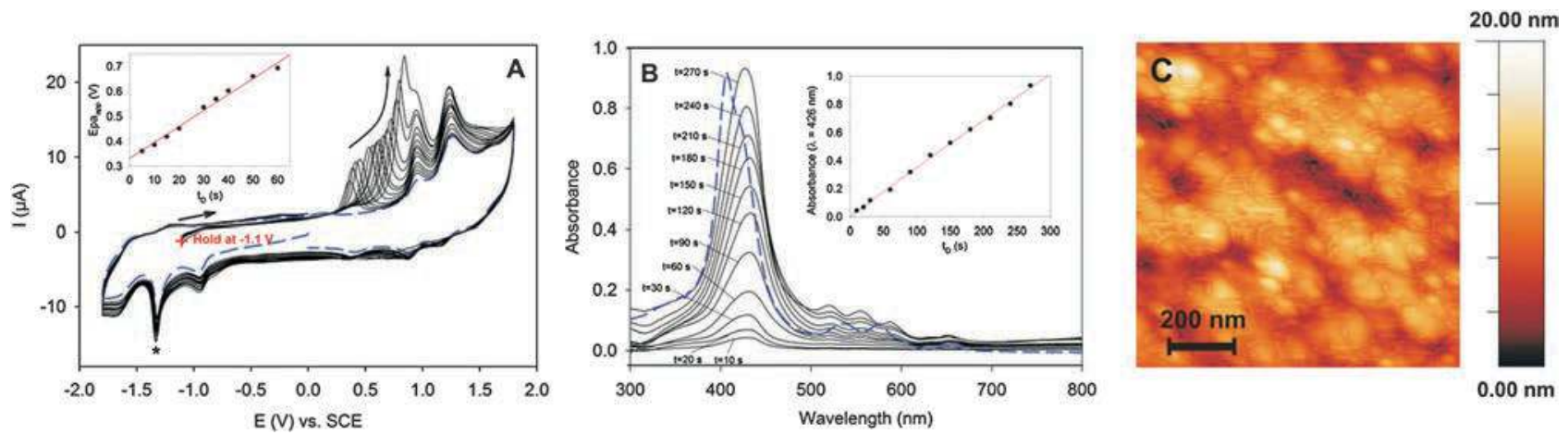

Fig. 7 (A) $\mathrm{CVs}$ of the films obtained from $3-\mathrm{H}_{2}-\mathrm{Zn}$ after different deposition times $\left(t_{\mathrm{D}}\right)$ at an applied potential equal to $-1.1 \mathrm{~V} / \mathrm{SCE}$ (dashed line: $\mathrm{CV}$ of $3-\mathrm{H}_{2}-\mathrm{Zn}$ in $\mathrm{CH}_{3} \mathrm{CN}$ containing $0.1 \mathrm{~mol} \mathrm{~L}^{-1} \mathrm{NBu}_{4} \mathrm{PF}_{6}$; working electrode: glassy carbon); (*) a cathodic redissolution process which ensues from the reduction of the insoluble "tetramers" at the surface of the working electrode. Inset: Epa $a_{\mathrm{app}}=f\left(t_{\mathrm{D}}\right)$ for the wave corresponding to the oxidation of the "tetramer". (B) UV-vis absorption spectra of the films deposited onto an ITO electrode after different $t_{\mathrm{D}}$ (dashed line: UV-vis absorption spectrum of $3-\mathrm{H}_{2}-\mathrm{Zn}$ in 1,2- $\mathrm{C}_{2} \mathrm{H}_{4} \mathrm{Cl}_{2}$ ). Inset: $\mathrm{Abs}=f\left(t_{\mathrm{D}}\right)$ at $426 \mathrm{~nm}$. (C) Atomic force micrograph of a coated ITO electrode obtained after a deposition time equal to $60 \mathrm{~s}$.

the electrolysis allowing the reduction of the pyridinium spacer. This is in good agreement with the expected absence of the coupling process in the case of this dimer.

In order to try to characterize the tetramer of porphyrins resulting from the coupling of two $3-\mathrm{H}_{2}-\mathrm{Zn}$ dimers, similar polarizations at $-1.1 \mathrm{~V} / \mathrm{SCE}$ have been performed on transparent ITO electrodes where the UV-visible absorption spectra (Fig. 7B) can be obtained. A red-shift of $c a .20 \mathrm{~nm}$ is observed for the Soret band of the tetramer of porphyrins compared to that of the dimer $3-\mathrm{H}_{2}-\mathrm{Zn}$. This red-shift is rather surprising since the tetramer of porphyrins results from a coupling of the reduced electron-withdrawing pyridinium groups. Consequently, a blue-shift was expected. The red-shift can be tentatively explained by the existence of important interactions between the macrocycles within the deposits on the electrode, in agreement with the formation of aggregates. Indeed, J-type aggregates between macrocycles could be present when a red-shift is observed, according to the report of Kasha. ${ }^{37}$

\section{Conclusion}

Two porphyrin dimers with pyridinium as bridging spacer have been obtained by controlled potential electrolysis. This method is based on a nucleophilic substitution of a porphyrin substituted by a pyridyl group $\left(\mathrm{H}_{2} \mathrm{~T}_{3} \mathrm{P}-x\right.$-Py, $x=3$ or 4$)$ on an electrogenerated radical cation of another porphyrin ( $\mathrm{ZnOEP})$. In order to study the influence of the angle between the two macrocycles, two isomers of the $\mathrm{H}_{2} \mathrm{~T}_{3} \mathrm{P}-x$-Py have been used, where the pyridyl group was either in the para position $\left(\mathrm{H}_{2} \mathrm{~T}_{3} \mathrm{P}-4-\mathrm{Py}\right)$ or in the meta position $\left(\mathrm{H}_{2} \mathrm{~T}_{3} \mathrm{P}-3-\mathrm{Py}\right)$. To our knowledge, they are the two first examples of porphyrin dimers with pyridinium spacers.

UV-vis absorption spectra of these two synthesized dimers have shown the presence of excitonic interactions between the porphyrin subunits. Concerning the fluorescence spectra, a total quenching of the luminescence has been observed.

The electrochemical study of these two dimers has been carried out by cyclic voltammetry. The dimers exhibit an electrochemical behaviour that is close to that of the individual porphyrins in the cathodic region. Nevertheless, the electron-withdrawing character of the pyridinium spacer induces an anodic shift of the oxidation potentials of the two porphyrins. Moreover, pyridinium spacers are also electroactive. Indeed, a new wave is observed in the cathodic part for these two dimers. Regarding the $4-\mathrm{H}_{2}-\mathrm{Zn}$ dimer, this wave is reversible while in the case of the $3-\mathrm{H}_{2}-\mathrm{Zn}$ dimer, it is quasi irreversible. In addition, this pyridinium spacer is more easily reduced in the case of the $4-\mathrm{H}_{2}-\mathrm{Zn}$ compound. To explain these observations, we have invoked the different delocalisation possibilities of the radical coming from the pyridinium reduction, leading to a better stabilisation of this radical in the case of the $4-\mathrm{H}_{2}-\mathrm{Zn}$ dimer. On the contrary, in the case of the $3-\mathrm{H}_{2}-\mathrm{Zn}$ dimer, this radical appears more reactive. Formation of a tetramer has been mentioned, which has been studied in more detail after obtainment by electrolysis.

\section{Experimental section}

\section{Chemicals}

All solvents were of reagent grade quality and used without further purification.

The zinc- $\beta$-octaethylporphyrin (ZnOEP) was purchased from Sigma-Aldrich. The 5,10,15-tritolyl-20-(4-pyridyl)porphyrin $\left(\mathrm{H}_{2} \mathrm{~T}_{3} \mathrm{P}-4-\mathrm{Py}\right)$ and the 5,10,15-tritolyl-20-(3-pyridyl)porphyrin $\left(\mathrm{H}_{2} \mathrm{~T}_{3} \mathrm{P}-3-\mathrm{Py}\right)$ were prepared according to a modified literature method. ${ }^{38}$

\section{Electrochemistry}

All electrochemical measurements were carried out under argon with a standard three-electrode system using a PARSTAT 2273 potentiostat. The working electrode was a glassy carbon disk electrode $(d=3 \mathrm{~mm})$. A platinum wire was used as an auxiliary electrode. The reference electrode was a saturated calomel electrode (SCE) that was electrically connected to the studied solution by a junction bridge filled with the corresponding solvent-supporting electrolyte solution.

Electrosynthesis was performed using a large platinum wire as a working electrode. The anodic and cathodic compartments were separated by a fritted glass disk to prevent diffusion of the electrogenerated species. 
A one sided indium-tin-oxide (ITO, Aldrich, 8-12 $\Omega$ per square) electrode with a surface of about $1 \mathrm{~cm}^{2}$ was used to prepare tetramer porphyrin films with various deposition times $\left(t_{\mathrm{D}}\right)$.

\section{Spectroscopic measurements}

UV-visible spectra were recorded with a Hewlett-Packard HP8453 spectrophotometer. Steady-state luminescence emission spectra were obtained using a Spex fluorolog 1681 spectrofluorimeter.

\section{Spectroelectrochemistry}

Spectroelectrochemical measurements were carried out using a potentiostat/galvanostat (EI30 M Brucker) and a diode array spectrophotometer (Hewlett-Packard 8453A). A homemade borosilicate glass cell with an optical pathway of $0.1 \mathrm{~mm}$ was used. The working electrode was a platinum grid (1000 mesh) placed in the optical pathway, the auxiliary electrode was a platinum wire, and the reference electrode was an aqueous $\mathrm{Ag} \mid \mathrm{AgCl}$ electrode.

\section{Atomic force microscopy}

AFM was performed directly on the surface of the ITO electrode using a Dimension 3100 (Veeco) in the tapping mode under ambient conditions. Silicon cantilevers (Veeco probes) with a spring constant of $300 \mathrm{~N} \mathrm{~m}^{-1}$ and a resonance frequency in the range of $120-139 \mathrm{kHz}$ were used. The scanning rate was $1.0 \mathrm{~Hz}$.

\section{Electrosynthesis}

4- $\mathrm{H}_{2}-\mathrm{Zn}: 10 \mathrm{mg}$ of $\mathrm{ZnOEP}\left(1.67 \times 10^{-5} \mathrm{~mol}\right)$ and $11 \mathrm{mg}$ of $\mathrm{H}_{2} \mathrm{~T}_{3} \mathrm{P}$-4-Py $\left(1.67 \times 10^{-5} \mathrm{~mol}\right)$ were dissolved in $100 \mathrm{~mL}$ of a 1,2- $\mathrm{C}_{2} \mathrm{H}_{4} \mathrm{Cl}_{2} / \mathrm{CH}_{3} \mathrm{CN}$ (3:1) solution containing $0.1 \mathrm{~mol} \mathrm{~L}-1$ tetraethylammonium hexafluorophosphate. $10 \mu \mathrm{L}$ of 2,6-lutidine were added to the solution. This compound acts as a base with the protons released during the synthesis. Then an electrolysis was carried out for $24 \mathrm{~h}$ at $0.75 \mathrm{~V}$ vs. SCE. Indeed, the electrolysis was stopped when the current value had reached the residual current value. During this anodic oxidation, the electrolyzed solution was continuously stirred and maintained under argon. After electrolysis, the initial red solution had turned brown, and the number of electrons per molecule of $\mathrm{ZnOEP}$ transferred was found to be equal to 2.1 electrons. Then the solvents were removed, and the residue was dissolved in $100 \mathrm{~mL}$ of $1,2-\mathrm{C}_{2} \mathrm{H}_{4} \mathrm{Cl}_{2}$. This organic solution was washed ten times with water in order to remove the supporting electrolyte. The organic layer was concentrated $(\sim 5 \mathrm{~mL})$ and chromatographed on silica. The first and the second fractions (eluted with $\mathrm{CH}_{2} \mathrm{Cl}_{2}$ ) were the unreacted $\mathrm{ZnOEP}$ and $\mathrm{H}_{2} \mathrm{~T}_{3} \mathrm{P}-4-\mathrm{Py}$, respectively. The third fraction (eluted with a mixture of $\mathrm{CH}_{2} \mathrm{Cl}_{2} / \mathrm{CH}_{3} \mathrm{OH}(99.75: 0.25)$ ) was the dimer $4-\mathrm{H}_{2}-\mathrm{Zn}$. The solvent was removed and $4-\mathrm{H}_{2}-\mathrm{Zn}$ was obtained (20.2 mg, 87\%).

UV-vis $\lambda_{\max }\left(1,2-\mathrm{C}_{2} \mathrm{H}_{4} \mathrm{Cl}_{2}\right) / \mathrm{nm} \quad 407 \quad\left(\varepsilon / \mathrm{dm}^{3} \quad \mathrm{~mol}^{-1} \mathrm{~cm}^{-1}\right.$ $108500), 537$ (7400), 579 (11200) and 671 (3900). NMR $\delta_{\mathrm{H}}\left(300 \mathrm{MHz} ;\left(\mathrm{CD}_{3}\right)_{2} \mathrm{CO} ; \mathrm{Me}_{4} \mathrm{Si} ; 25{ }^{\circ} \mathrm{C}\right) 10.87\left(2 \mathrm{H}, \mathrm{d}, \mathrm{Py}^{+}\right)$, $10.52(2 \mathrm{H}, \mathrm{s}$, meso-H), $10.41(1 \mathrm{H}, \mathrm{s}$, meso $-\mathrm{H}), 9.70(2 \mathrm{H}, \mathrm{d}$, $\left.\mathrm{Py}^{+}\right), 9.38(2 \mathrm{H}, \mathrm{d}, \beta-\mathrm{H}), 9.30(2 \mathrm{H}, \mathrm{d}, \beta-\mathrm{H}), 9.00(4 \mathrm{H}, \mathrm{s}, \beta-\mathrm{H})$,
8.26 (4H, d, tolyl), 8.18 (2H, d, tolyl), 7.77 (4H, d, tolyl), 7.69 (2H, d, tolyl), $4.24\left(4 \mathrm{H}, \mathrm{q},{ }^{3} \mathrm{~J}=7.5 \mathrm{~Hz}, 2 \mathrm{CH}_{2}\right.$ of $\left.-\mathrm{CH}_{2}-\mathrm{CH}_{3}\right)$, $4.14\left(8 \mathrm{H}, \mathrm{q},{ }^{3} \mathrm{~J}=7.5 \mathrm{~Hz}, 4 \mathrm{CH}_{2}\right.$ of $\left.-\mathrm{CH}_{2}-\mathrm{CH}_{3}\right), 3.22\left(4 \mathrm{H}, \mathrm{q},{ }^{3} J=\right.$ $7.5 \mathrm{~Hz}, 2 \mathrm{CH}_{2}$ of $\left.-\mathrm{CH}_{2}-\mathrm{CH}_{3}\right), 2.66\left(9 \mathrm{H}, \mathrm{s}, \mathrm{CH}_{3}\right.$ of tolyl), 1.87 $\left(12 \mathrm{H}, \mathrm{t},{ }^{3} \mathrm{~J}=7.5 \mathrm{~Hz}, 4 \mathrm{CH}_{3}\right.$ of $\left.-\mathrm{CH}_{2}-\mathrm{CH}_{3}\right), 1.81\left(6 \mathrm{H}, \mathrm{t},{ }^{3} \mathrm{~J}=\right.$ $7.5 \mathrm{~Hz}, 2 \mathrm{CH}_{3}$ of $\left.-\mathrm{CH}_{2}-\mathrm{CH}_{3}\right), 1.24\left(6 \mathrm{H}, \mathrm{t},{ }^{3} \mathrm{~J}=7.4 \mathrm{~Hz}, 2 \mathrm{CH}_{3}\right.$ of $-\mathrm{CH}_{2}-\mathrm{CH}_{3}$ adjacent to $\left.\mathrm{Py}^{+}\right)$, and $-2.48(2 \mathrm{H}, \mathrm{s}, \mathrm{NH})$. HR-MS $m / z$ : 1252.5677; calculated for $\left[\mathrm{ZnC}_{82} \mathrm{H}_{78} \mathrm{~N}_{9}{ }^{+}\right]$]: 1252.5688 . Molecular mass: $\left[\mathrm{ZnC}_{82} \mathrm{H}_{78} \mathrm{~N}_{9}{ }^{+}\right]\left(M=1254.96 \mathrm{~g} \mathrm{~mol}^{-1}\right)$.

$3-\mathrm{H}_{2}-\mathrm{Zn}$ : this second dimer was obtained by the same procedure using $\mathrm{H}_{2} \mathrm{~T}_{3} \mathrm{P}-3-\mathrm{Py}$ in the place of $\mathrm{H}_{2} \mathrm{~T}_{3} \mathrm{P}-4-\mathrm{Py}$. Then $3-\mathrm{H}_{2}-\mathrm{Zn}$ was obtained with a yield of $85 \%(19.7 \mathrm{mg}$, $\left.1.41 \times 10^{-5} \mathrm{~mol}\right)$.

UV-vis $\lambda_{\max }\left(1,2-\mathrm{C}_{2} \mathrm{H}_{4} \mathrm{Cl}_{2}\right) / \mathrm{nm} \quad 407 \quad\left(\varepsilon / \mathrm{dm}^{3} \mathrm{~mol}^{-1} \mathrm{~cm}^{-1}\right.$ 137600), 535 (13200), 576 (13000) and 657 (3000). NMR $\delta_{\mathrm{H}}\left(300 \mathrm{MHz} ;\left(\mathrm{CD}_{3}\right)_{2} \mathrm{CO} ; \mathrm{Me}_{4} \mathrm{Si} ; 25^{\circ} \mathrm{C}\right) 11.35\left(1 \mathrm{H}, \mathrm{d}, \mathrm{Py}^{+}\right)$, $10.99\left(1 \mathrm{H}, \mathrm{s}, \mathrm{Py}^{+}\right), 10.44\left(1 \mathrm{H}, \mathrm{d}, \mathrm{Py}^{+}\right), 10.42(2 \mathrm{H}, \mathrm{s}$, meso-H), $10.31\left(1 \mathrm{H}, \mathrm{s}\right.$, meso-H), $9.52\left(1 \mathrm{H}, \mathrm{dd}, \mathrm{Py}^{+}\right), 9.44(2 \mathrm{H}, \mathrm{d}, \beta-\mathrm{H})$, $9.16(2 \mathrm{H}, \mathrm{d}, \beta-\mathrm{H}), 8.90(4 \mathrm{H}, \mathrm{s}, \beta-\mathrm{H}), 8.17(4 \mathrm{H}, \mathrm{m}$, tolyl $), 8.04$ (2H, m, tolyl), 7.74 (4H, m, tolyl), 7.65 (2H, m, tolyl), 4.17 $\left(4 \mathrm{H}, \mathrm{q},{ }^{3} \mathrm{~J}=7.5 \mathrm{~Hz}, 2 \mathrm{CH}_{2}\right.$ of $\left.-\mathrm{CH}_{2}-\mathrm{CH}_{3}\right), 4.11\left(8 \mathrm{H}, \mathrm{q},{ }^{3} \mathrm{~J}=\right.$ $7.5 \mathrm{~Hz}, 4 \mathrm{CH}_{2}$ of $\left.-\mathrm{CH}_{2}-\mathrm{CH}_{3}\right), 3.23\left(4 \mathrm{H}, \mathrm{q},{ }^{3} \mathrm{~J}=7.5 \mathrm{~Hz}, 2 \mathrm{CH}_{2}\right.$ of $\left.-\mathrm{CH}_{2}-\mathrm{CH}_{3}\right), 2.67\left(9 \mathrm{H}, \mathrm{s}, \mathrm{CH}_{3}\right.$ of tolyl), $1.89\left(12 \mathrm{H}, \mathrm{t},{ }^{3} \mathrm{~J}=\right.$ $7.5 \mathrm{~Hz}, 4 \mathrm{CH}_{3}$ of $\left.-\mathrm{CH}_{2}-\mathrm{CH}_{3}\right), 1.83\left(6 \mathrm{H}, \mathrm{t},{ }^{3} \mathrm{~J}=7.5 \mathrm{~Hz}, 2 \mathrm{CH}_{3}\right.$ of $\left.-\mathrm{CH}_{2}-\mathrm{CH}_{3}\right), 1.19\left(6 \mathrm{H}, \mathrm{t},{ }^{3} \mathrm{~J}=7.4 \mathrm{~Hz}, 2 \mathrm{CH}_{3}\right.$ of $-\mathrm{CH}_{2}-\mathrm{CH}_{3}$ adjacent to $\left.\mathrm{Py}^{+}\right)$, and $-2.74(2 \mathrm{H}, \mathrm{s}, \mathrm{NH})$. HR-MS $m / z$ : 1252.5666; calculated for $\left[\mathrm{ZnC}_{82} \mathrm{H}_{78} \mathrm{~N}_{9}{ }^{+}\right]$: 1252.5688 . Molecular mass: $\left[\mathrm{ZnC}_{82} \mathrm{H}_{78} \mathrm{~N}_{9}{ }^{+}\right]\left(M=1254.96 \mathrm{~g} \mathrm{~mol}^{-1}\right)$.

\section{Acknowledgements}

This work was supported by the CNRS, the Universite Paris-Sud (Paris 11, Orsay), the Universite de Strasbourg, the Université Paris Descartes (Paris 5), the Université Pierre et Marie Curie (Paris 6) and the ECE Paris Ecole d'Ingénieurs. The authors thank also R. Thouvenot and B. Hasenknopf, Institut Parisien de Chimie Moléculaire, UMR 7201 CNRSUniversité Paris 6, for the NMR and HR-MS mass spectroscopies.

\section{References}

1 M. Gouterman, The porphyrins, vol. 3, Academic Press, 1978.

2 K. M. Kadish, K. M. Smith and R. Guilard, The porphyrin handbook, vol. 8, Academic Press, 2000.

3 L. R. Milgrom, The colours of life: an introduction to the chemistry of porphyrins and related compounds, Oxford University Press, 1997

4 S. G. Boxer, Biochim. Biophys. Acta, 1983, 726, 265-292.

5 M. R. Wasielewski, Photochem. Photobiol., 1988, 47, 923-929.

6 D. Gust and T. A. Moore, Science, 1989, 244, 35-41.

7 L. Ruhlmann, A. Nakamura, J. G. Vos and J.-H. Fuhrhop, Inorg. Chem., 1998, 37, 6052-6059.

8 S. Punidha and M. Ravikanth, Tetrahedron, 2004, 60, 8437-8444.

9 E. Vanover, Y. Huang, L. Xu, M. Newcomb and R. Zhang, Org. Lett., 2010, 12, 2246-2249.

10 A. Osuka and H. Shimidzu, Angew. Chem., Int. Ed. Engl., 1997, 36, 135-137.

11 R. G. Khoury, L. Jaquinod and K. M. Smith, Chem. Commun., 1997, 1057-1058.

12 M. G. H. Vicente, L. Jaquinod and K. M. Smith, Chem. Commun., 1999, 1771-1782.

13 K. F. Cheng, C. M. Drain and K. Grohmann, Inorg. Chem., 2003, 42, 2075-2083. 
14 T.-H. Huang, Y.-J. Chen, S.-S. Lo, W.-N. Yen, C.-L. Mai, M.-C. Kuo and C.-Y. Yeh, Dalton Trans., 2006, 2207-2213.

15 N. N. Sergeeva, A. Scala, M. A. Bakar, G. O'Riordan, J. O'Brien, G. Grassi and M. O. Senge, J. Org. Chem., 2009, 74, 7140-7147.

16 X.-L. Jiang, H.-L. Zhang and J. Wu, Heterocycles, 2006, 68, 2153-2160.

17 L. Ruhlmann and A. Giraudeau, Eur. J. Inorg. Chem., 2001, 659-668.

18 L. Ruhlmann, M. Gross and A. Giraudeau, Chem.-Eur. J., 2003, 9, 5085-5096.

19 A. Giraudeau, L. Ruhlmann, L. El-Kahef and M. Gross, J. Am. Chem. Soc., 1996, 118, 2969-2979.

20 K. Kalyanasundaram and M. Neumann-Spallart, J. Phys. Chem., 1982, 86, 5163-5169.

21 K. Kalyanasundaram, Inorg. Chem., 1984, 23, 2453-2459.

22 D. Schaming, A. Giraudeau, S. Lobstein, R. Farha, M. Goldmann, J.-P. Gisselbrecht and L. Ruhlmann, J. Electroanal. Chem., 2010, 635, 20-28.

23 N. Karakostas, D. Schaming, S. Sorgues, S. Lobstein, J.-P. Gisselbrecht, A. Giraudeau, I. Lampre and L. Ruhlmann, J. Photochem. Photobiol., A, 2010, 213, 52-60.

24 J. Fajer, D. C. Borg, A. Forman, D. Dolphin and R. H. Felton, J. Am. Chem. Soc., 1970, 92, 3451-3459.

25 J.-H. Fuhrhop, K. M. Kadish and D. G. Davis, J. Am. Chem. Soc., 1973, 95, 5140-5147.
26 D. Dolphin and R. H. Felton, Acc. Chem. Res., 1974, 7, 26-32.

27 H. Garcìa-Ortega, J. Crusats, M. Feliz and J. M. Ribò, J. Org. Chem., 2002, 67, 4170-4176.

28 J. Hirota and I. Okura, J. Phys. Chem., 1993, 97, 6867-6870.

29 A. Giraudeau, S. Lobstein, L. Ruhlmann, D. Melamed, K. M. Barkigia and J. Fajer, J. Porphyrins Phthalocyanines, 2001, 5, 793-797.

30 V. Carelli, F. Liberatore, A. Casini, S. Tortorella, L. Scipione and B. D. Renzo, New J. Chem., 1998, 22, 999-1004.

31 V. Carelli, F. Liberatore, S. Tortorella, B. D. Rienzo and L. Scipione, J. Chem. Soc., Perkin Trans. 1, 2002, 542-547.

32 A. Brisach-Wittmeyer, S. Lobstein, M. Gross and A. Giraudeau, J. Electroanal. Chem., 2005, 576, 129-137.

33 J. Volke, J. Urban and V. Volkeova, Electrochim. Acta, 1992, 37, 2481-2490.

34 J. Volke, L. Dunsch, V. Volkeovà, A. Petr and J. Urban, Electrochim. Acta, 1997, 42, 1771-1780.

35 J. E. H. Buston, F. Marken and H. L. Anderson, Chem. Commun., 2001, 1046-1047.

36 C. Inisan, J.-Y. Saillard, R. Guilard, A. Tabard and Y. L. Mest, New J. Chem., 1998, 22, 823-830.

37 M. Kasha, Radiat. Res., 1963, 20, 55-71.

$38 \mathrm{~K}$. Funatsu, T. Imamura, A. Ichimura and Y. Sasaki, Inorg. Chem., 1998, 37, 1798-1804. 